\title{
炭化ケイ素セラミックスの耐酸化性評価
}

\author{
前田稕・中村和雄・東伸行
}

(名古屋工業技術試験所，462 名古屋市北区平手町 1-1)

\section{Evaluation of the Oxidation Resistance of Silicon Carbide Ceramics}

\author{
Minoru MAEDA, Kazuo NAKAMURA and Nobuyuki AZUMA \\ (Government Industrial Research Institute, Nagoya, 1-1, Hirate-cho, Kita-ku, Nagoya-shi \\ 462)
}

Five kinds of silicon carbide ceramics were oxidized in flowing dry air at $1300^{\circ} \mathrm{C}$ for $360 \mathrm{~h}$ and $1000 \mathrm{~h}$, and oxidation behaviour was studied by measuring the weight gain and thickness of oxide layer and of unoxidized substrate, in which the weight loss by evaporation of some species from the oxide layer during oxidation was taken into account. The change of thickness of substrate was complicated, and some samples expanded during oxidation. Therefore, no direct correlation is possible between evapolation and dimensional change of substrate. To evaluate the oxidation resistance correctly, the thickness, density and texture of the oxide layer must be examined together with the weight gain.

[Received November 4, 1987; Accepted March 24, 1988]

Key-words : Silicon carbide, Engineering ceramics, Oxidation, Evaluation, Oxide layer, Weight gain

\section{1. 緒言}

炭化ケイ素は高温強度が大きく, 高い熱伝導率, 低い 熱膨張率，耐酸化性に優れているなどの特徴を有し，耐 熱構造材料として期待される. したがって炭化ケイ素焼 結体についての高温における酸化挙動に関しては多くの 報告がある11 3!

$\mathrm{SiC}, \mathrm{Si}_{3} \mathrm{~N}_{4}$ などの共有結合性の高い材料は難焼結性 であるため，緻密な焼結体を得るために，一般に焼結助 剂が使われている。これにより粒界での拡散を促進し， 液相焼結あるいは固相焼結を進行させる.

助剂としては $\mathrm{Al}_{2} \mathrm{O}_{3}, \mathrm{Y}_{2} \mathrm{O}_{3}, \mathrm{MgO}, \mathrm{B}, \mathrm{C}$ などが使わ れ，これらを単独あるいは複数の組み合わせで添加され ている(4) 6).

耐酸化性評価は， $\mathrm{SiC}, \mathrm{Si}_{3} \mathrm{~N}_{4}$, サイアロンなどの酸 化が重量増加を示すことから，その変化を調べることが 簡単でもあり一般的である71. しかしながら, 前述のよ うに添加剤の種類によっては, 酸化生成物中に $\mathrm{B}_{2} \mathrm{O}_{3}$ な どのように蒸発するものがあり, 重量変化がそのまま正 しく耐酸化性を反映せず，酸化初期に重量減少が観察さ れる場合もあるので留意する必要がある ${ }^{81,99}$.

本法は，実際には大きい酸化が起こっているにもかか わらず, 蒸発による減量も大きいため, 酸化重量増とし ては見掛け上小さい值を示すであろう特異な酸化過程を 想定して, 酸化重量増と酸化生成物の膜厚測定の外に, 表面酸化膜の厚さを除いた未酸化部分（基体）の厚さを 酸化処理後に測定して,酸化処理前の基体厚さと比較し, 酸化過程における試料表面からの反応生成物等の蒸発に よる減量の影響も考虑に入れた耐酸化性評価を試みた。

\section{2. 実 験}

用いた試料は，助剂として $\mathrm{Al}_{2} \mathrm{O}_{3}$ を使ったもの $\mathrm{A}-1$, A-2 の 2 種, B と $\mathrm{C}$ を助剂とした BC-1, BC-2, $\mathrm{BC}-3$ の 3 種の計 5 種である.

試料の諸性質を表 1 に示す.

試料形状は JIS R 1601 のファインセラミックスの曲 げ試験法に準じて， $3 \times 4 \times 40 \mathrm{~mm}$ の角棒状とし，表面 粗さは最大高さ $0.8 \mu \mathrm{m}$ 以下に研磨した.

試料は高純度アルミナ製セッター上に並ベ，これを高 アルミナ質マツフルの中に入れて, 箱形電気炉により耐 酸化性評価試験を行った。

試験温度は $1300^{\circ} \mathrm{C}$, 酸化時間は $360 \mathrm{~h}$ 及び $1000 \mathrm{~h}$ の 2 通り, 酸化雾囲気はシリカゲル及びモレキュラーシー ブで乾燥した空気流中である (毎分 $1.07 \mathrm{~L}$ ).

各試料ごとに 3 本をテストし, その中の 1 本は標準長 さ $40 \mathrm{~mm}$ の 1 端から $3 \times 4 \times 4 \mathrm{~mm}$ の試験片（これを小 試片, 残りの約 $3 \times 4 \times 36 \mathrm{~mm}$ の長い方を大試片と呼称） を切り出し，己れを基体厚さの変化を測定する際の酸化 処理前の標準試料片とした。

これは, 標準長さ試料の長手方向の平行度の偏倚によ る誤差をさけるため,酸化処理前後の基体厚さの測定は, この切断面の両面を使って比較するためである.ただし， 大小両試片とも走查型電子顕微鏡 (SEM) 観察するため, この切断面を鏡面研磨した。

研磨後, この両試片を SEM の試料載台に平行に並置 し，始めに小試片及び大試片の一方の端の表面に焦点を あて拡大写真を取り $(1000 \times$ を標準とした $)$, 次に SEM 鏡下でステージを移動して他端の拡大写真を撮っ 
Table 1. Properties of silicon carbide ceramics.

\begin{tabular}{|c|c|c|c|c|c|c|}
\hline \multicolumn{2}{|c|}{ specimen } & $A-1$ & $A-2$ & $\mathrm{BC}-1$ & $\mathrm{BC}-2$ & $\mathrm{BC}-3$ \\
\hline \multicolumn{2}{|c|}{ sintering aid } & $\mathrm{Al}_{2} \mathrm{O}_{3}$ & $\mathrm{Al}_{2} \mathrm{O}_{3}$ & $\mathrm{~B}+\mathrm{C}$ & $\mathrm{B}+\mathrm{C}$ & $\mathrm{B}+\mathrm{C}$ \\
\hline \multicolumn{2}{|c|}{$\begin{array}{l}\text { sintering } \\
\text { process }\end{array}$} & HIP & $\begin{array}{l}\text { pressure- } \\
\text { less }\end{array}$ & $\begin{array}{l}\text { pressure- } \\
\text { less }\end{array}$ & $\begin{array}{l}\text { pressure- } \\
\text { less }\end{array}$ & $\begin{array}{l}\text { pressure- } \\
\text { less }\end{array}$ \\
\hline \multirow{4}{*}{ 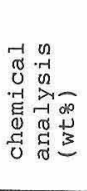 } & Al & 2.45 & 2.44 & 0.02 & 0.05 & 0.02 \\
\hline & $\mathrm{B}$ & 0.006 & 0.001 & 0.25 & 0.57 & 0.60 \\
\hline & free $C$ & 0.18 & 0.05 & 0.25 & 2.85 & 1.45 \\
\hline & total C & 27.2 & 27.0 & 29.7 & 30.2 & 31.8 \\
\hline \multicolumn{2}{|c|}{ bulk density } & 3.193 & 3.188 & 3.036 & 3.075 & 3.000 \\
\hline \multicolumn{2}{|c|}{ porosity (웅 } & 0.112 & 0.096 & 0.262 & 0.166 & 0.319 \\
\hline
\end{tabular}

た.このようにすることにより,平行移動を同一ストロー クにして，大小武片を別々に走查する場合に入る送り誤 差の介入をさけた。

ステージ移動の前後には, ステージ付属のコンピュー ター制御によるマイクロメーターの指示值を読み取っ た。拡大写真を撮る場合，同一視野に大小両試片の端面 を撮影することはできないから，ステージを $X$ 軸方向 に移動させて，大小いずれか一つずつ試片の端面を視野 に入れて撮影することになる.

かくして写真上で試料の酸化膜の厚さ, 基体の厚さを 測定し, また天科により酸化重量増を測定した。

\section{3. 結果と考察}

5 種の炭化ケイ素の酸化試験結果を図 1 に示す. $360 \mathrm{~h}$ 酸化では, いずれの試料も基体の厚さは減少を

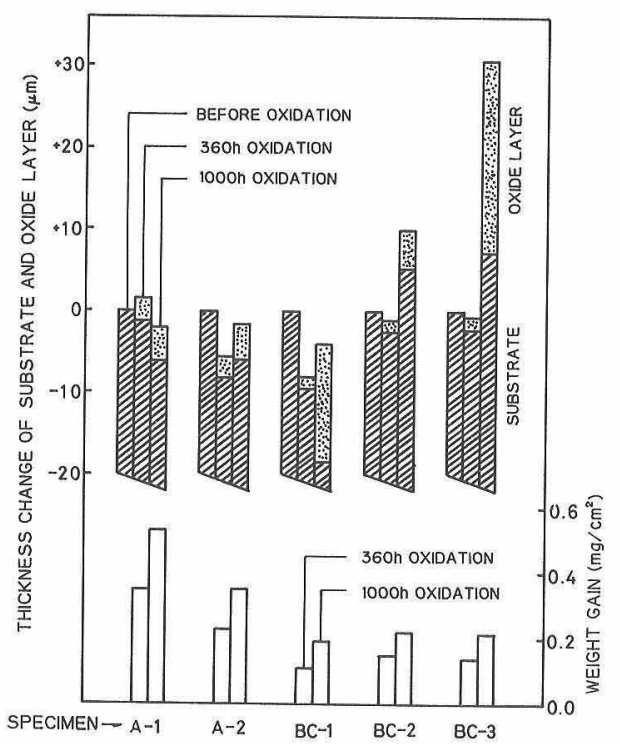

Fig. 1. Thickness change of substrate and oxide layer and weight gain by oxidation.
示し, 酸化膜を生成し, 酸化による重量増加を示した。 酸化増量と酸化膜厚はほぼ比例関係にある。

表 1 から、A-1，A-2 試料は分析值，かさ比重，気孔 率いずれも極めて近似した值を示すが， $360 \mathrm{~h}$ 酸化によ る基体の厚さの変化は $\mathrm{A}-1$ 試料に比べて $\mathrm{A}-2$ 試料が大 きい変化を示した，しかしながら，酸化膜厚は両者同程 度であり, 酸化増量はA-1 試料の方が大きい值を示し た.

これらの現象の相関は現在明確にできないが，酸化現 象に対する出発物質, 製法等の違いによる特性要因が複 雑に関与しているものと思われる ${ }^{3}$.

$\mathrm{BC}-1, \mathrm{BC}-2, \mathrm{BC}-3$ 試料はいずれも常圧焼結体であ り, A-1, A-2 試料に比べてかさ比重は小さく, 気孔率 は大きくて組織が粗であることが涊められた。

また $\mathrm{BC}-1, \mathrm{BC}-2, \mathrm{BC}-3$ 試料間では，ボロン (B), フリーカーボン,トータルカーボン量に差が認められた.

$360 \mathrm{~h}$ 酸化では, BC-1, BC-2，BC-3 試料中，かさ 比重が最も大きく、気孔率が最も小さい, したがって組 織が最も緻密な BC-2 試料が，3 者中最も粗な組織を有 する BC-3 試料と同程度の酸化挙動を示したのに対し て, 中間の密度をもつ $\mathrm{BC}-1$ 試料は, $\mathrm{BC}-2, \mathrm{BC}-3$ 試 料に比べて酸化増量は小さく, 基体厚さの変化は大きい 值を示した。

この例が示すように, 単純にかさ比重, 気孔率等だけ の比較から耐酸化性を推論するのは妥当ではない，組織 の粗密は耐酸化性に対して一つの要因にすぎない。

$1000 \mathrm{~h}$ 酸化では, 酸化増量と酸化膜厚との間に, 360 $\mathrm{h}$ 酸化で見られたような比例関係は認められない。

A-1，A-2 試料間では，基体厚さの変化，酸化膜厚の 差はいずれも小さく, 酸化増量は $\mathrm{A}-1$ が $\mathrm{A}-2$ よりも大 きい值を示した。

$\mathrm{BC}-1, \mathrm{BC}-2, \mathrm{BC}-3$ 試料間では, 酸化増量に関して は 3 者ともほとんど同じ值を示したが, 基体厚さの変化 及び酸化膜厚には大きな差が喼められた。この中, 
$\mathrm{BC}-2, \mathrm{BC}-3$ 試料では基体が酸化処理前よりも膨張し ている.すなわち組織が粗になる傾向が認められた。

酸化增量值の小さいものが, 必らずしも酸化膜厚が小 さいとはかぎらない， BC-1 試料は酸化増量值が小さい にもかかわらず酸化膜厚が大きく，基体厚さは大きく減 少している， BC-3 試料は酸化膜厚が大きくて，しかも 酸化処理前よりも基体が膨張している.

基体厚さの変化及び酸化膜厚が小さい点から，3者中 最も緻密な組織の $\mathrm{BC}-2$ 試料が, 酸化に刘して最も安 定な結果を示した。

$360 \mathrm{~h}$ と $1000 \mathrm{~h}$ 酸化を比較すると, いずれの試料も酸 化増量はほほ酸化時間に比例して増加しているが, 酸化 膜厚及び基体厚さの変化は必らずしも酸化時間に対して 各試料とも規則性は認められない。

酸化により表面に生成する酸化膜は，その組織が酸化 時間の経過とともに変化する（酸化生成物である気泡の 発生とその成長, 無定形酸化生成物加らの各喠結晶の析 出とその成長, 結晶の転移, ガラスの粘性の変化，ガラ 又と結晶の相対量の变化等 $\left.\left.)^{1)}, 2\right), 10\right), 11$ 。基体内部におい ても粒境界を通して物質の移動・拡散が進行するために 組織の経時的変化がおこる ${ }^{12 / 14)}$.

前述の酸化膜厚及び基体厚さの酸化時間に対する各試 料ごとの特異な変化挙動は, 助剤の種類と量, 試料中の 不純物の種類と量，製造方法等の違いが，各試料の酸化 過程に複雑に関与している結果である.

通常の蒸発が少ない酸化過程では, 酸化が進行するに したがって酸化重量が増加し，それにつれて酸化膜厚は 成長し，基体は表面から内部にむけて酸化が進行するに 従って徐々に厚さを減じていく之推定される.

蒸発が大きく関与する酸化では, 酸化重量の増加が, 基体厚さの減少及び酸化膜厚の増加の割合よりも相対的 に小さい值を示しながら進行することを想定したのであ るが，本実験の結果では酸化の過程で基体自体が膨張す ることが認められたので, 基体厚さの変化が小さくても,
このことが蒸発が起こらなかった根拠にはならないこと が分かった。

したがって, 酸化に付隨する蒸発減量の現象を基体厚 さの変化からとらえることは困難である.

一方, 酸化過程における蒸発物質としては, 助剈とし て添加される B や C などが主なるもので，酸化膜の主 成分である $\mathrm{SiO}_{2}$ の蒸発は, 本実験のごとく高酸化雾囲 気では極めて小さい(1),12) 14)。したがって前述したよう に，蒸発物質の含有が少ない試料では酸化が進行するに つれて, 酸化重量が増加するとともに酸化膜厚が増加す るが，酸化条件，試料の種類によって生成する酸化膜の 組織は異なる。すなわち，極めて緻密な組織のものから ポーラスな組織の酸化膜まで多種多様なものが生成する 可能性がある。そのために酸化增量が同值を示しても酸 化膜厚には差がある ${ }^{18)}$ 。

BC-1 試料については, 前述のように基体厚さの変化 が必ずしも蒸発現象を明確に反映していることにはなら ないが，実験值から判断すれば典型的な蒸発を伴った酸 化が進行した試料であることを示唆している. SEM 観 察によるとこの酸化膜の組織は粗であった。

$\mathrm{BC}-3$ 試料は酸化膜厚が大きい值を示すのに対して, その酸化増量は相対的に小さいが，この試料の酸化にも 蒸発が付隨していると推定される。

$1300^{\circ} \mathrm{C}, 1000 \mathrm{~h}$ 酸化後の BC-3 試料の断面の SEM 写真 (図 $2(a))$ を示す.

酸化膜は厚いが，大きい気泡を含み組織は粗である。 生成した酸化膜から概算した酸化増量値と実測值を対比 すると，本試料では蒸発による減量がないとすれば，酸 化増量は実測值よりも大きい值を示さねばならぬと推論 される。

これに対して，助剤が $\mathrm{Al}_{2} \mathrm{O}_{3}$ である A-1 試料の SEM 写真を図 2 (b ) に示す $\left(1300^{\circ} \mathrm{C}-1000 \mathrm{~h}\right.$, 断面). 酸化 膜厚は BC-3 よりはるかに小さいが, 酸化増量は大き い值を示している，すなわち，本武料では蒸発による減
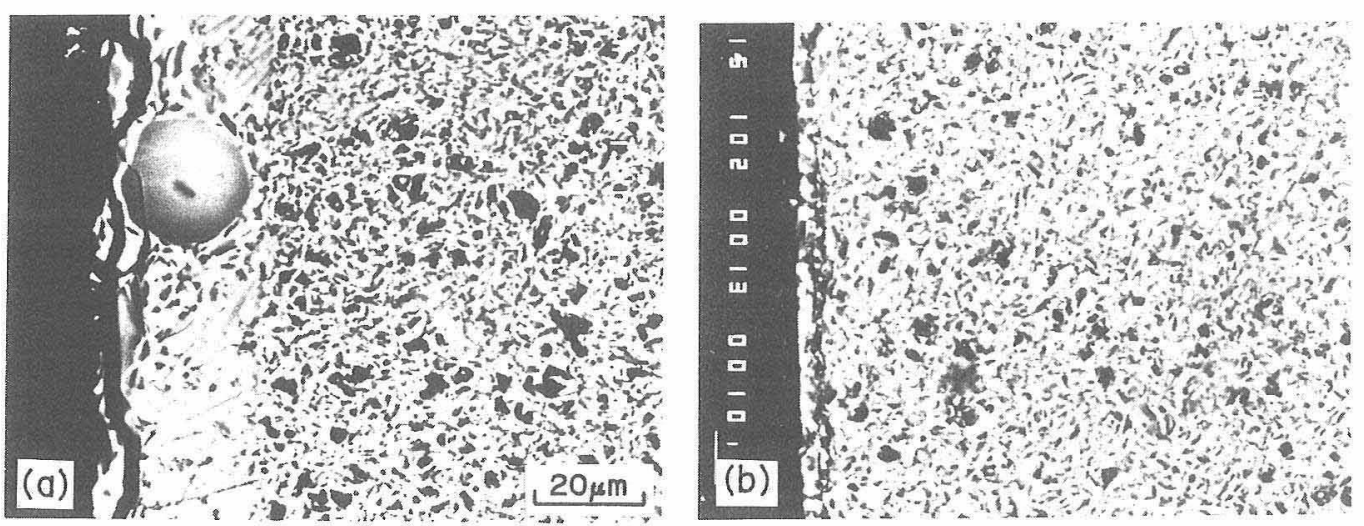

Fig. 2. SEM micrograph of cross-section $\left(1300^{\circ} \mathrm{C}, 1000 \mathrm{~h}\right.$, same magnifications $)$.

(a) $\mathrm{BC}-3$, (b ) A-1 
量は極めて少ないと考えられる。

耐酸化性評価において，酸化中に成分の 1 部が蒸発す るような試料については，酸化重量の測定だけでは誤っ た判定をする恐れがある。そこで酸化重量及び酸化膜厚 の測定に加えて基体厚さの变化を併行して測定を行なっ たが, 基体厚さの変化が必らすしも蒸発減量の現象を反 映しないことが分かった。したがって耐酸化性評価にお いて, 蒸発減量による酸化增量への影響を検討するには, 酸化膜の微構造, 特にその組織の粗密を解明することが 必要である，酸化増量值に対して酸化膜厚が異常に大き い試料については, 酸化の進行に伴う重量増加と同時に, 酸化生成物の蒸発による減量の可能性も想定して耐酸化 性を評価すべきである。

\section{文献}

1) S.C. Singhal, J. Mater. Sci., 11, 1246-53 (1976).

2) J.A. Costello and R. E. Tressler, J. Am. Ceram. Soc., 64, 327-31 (1981).

3) 長谷川安利, 広田和士, セラミックス, 18, 580-85 (1983)

4) 米屋勝利, セラミックス, 10，145-50 (1975).
5）鈴木弘茂, セラミックス, 18，3-9 (1983).

6) 猪股吉三，化学々工業，36，284-87 (1983).

7）鈴木弘茂監修, “エンジニアリングセラミックス”, シー エムシー (1983) p. 166.

8) J. Schlichtung and J. Kriegesmann, Ber, Dt. Keram. Ges., 56, 72-75 (1979).

9）阿部 弘，川合 実，菅野隆志，鈴木恵一朗，“エンジニ アリングセラミックス”, 技報堂 (1984) p. 161 .

10) D. M. Mieskowsky, T.E. Mitchell and A.H. Heuer, J. Am. Ceram. Soc., 67, C-17-18 (1984).

11) J.W. Hinze, W. C. Tripp and H. C. Graham, in "Mass Transport Phenomena in Ceramics", Editid by A.R. Cooper and A.H. Heuer, Plenum Press, New York (1975) p. 409.

12) J.A. Costello, R. E. Tressler and I. S. T. Tsong, J. Am. Ceram. Soc., 64, 332-35 (1981).

13) M. H. Lewis and P. Barnard, J. Mater. Sci., 15, 443-48 (1980).

14) D. Cubicciotti and K. H. Lau, J. Am. Ceram, Soc, 61, 512-17 (1978).

15) S. C. Singhal, J. Mater. Sci., 11, 500-09 (1976).

16) J.E. Sheehan, J. Am. Ceram. Soc., 65, C-111-13 (1982).

17) F. F. Lange, J. Am. Ceram. Soc, , 65, C-120-21 (1982).

18）長谷川安利, 広田和士, 山根典子, 三友 護, 鈴木弘茂, 窯協, 89, 144-56 (1981).

\section{訂 正}

日本セラミックス協会学術論文誌 96 [6] 694-97 (1988) 掲載の, 金 豪健・小久保 正 “ $\mathrm{Bi}_{2} \mathrm{O}_{3}\left(\mathrm{Nb}_{2} \mathrm{O}_{5}\right)-6 \mathrm{Bi}_{2} \mathrm{O}_{3}$ ・ $\mathrm{SiO}_{2}$ 系凝固物のキャッツ・アイ効果”の本文中, p. 697 の Fig. 8 と Fig. 9 の図が替わっていますので，下記のよう に訂正します.
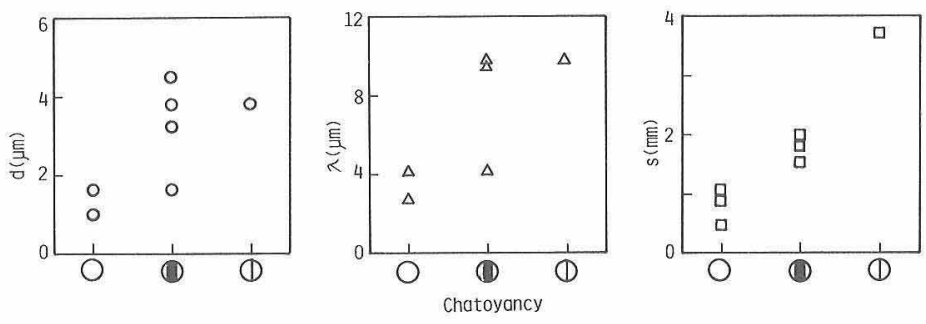

Fig. 8. Relations between chatoyancy and fiber diameter $(d)$, interfiber spacing $(\lambda)$ or cell diameter $(s)$.

Chatoyancy, $\bigcirc$; not observed, (1); observed but not clearly, (1); clearly observed.

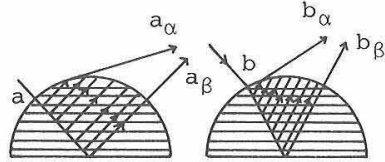

(A)

(B)

Fig. 9. Origin of chatoyancy of cat's eye stone. 